\title{
GCU
}

Glasgow Caledonian

University

University for the Common Good

\section{Gender analysis of spending on the Scottish Modern Apprenticeship programme}

Campbell, Jim; Gillespie, Morag

Published in:

Local Economy

DOI:

$10.1177 / 0269094217721669$

Publication date:

2017

Document Version

Author accepted manuscript

Link to publication in ResearchOnline

Citation for published version (Harvard):

Campbell, J \& Gillespie, M 2017, 'Gender analysis of spending on the Scottish Modern Apprenticeship programme', Local Economy, vol. 32, no. 5, pp. 420-432. https://doi.org/10.1177/0269094217721669

\section{General rights}

Copyright and moral rights for the publications made accessible in the public portal are retained by the authors and/or other copyright owners and it is a condition of accessing publications that users recognise and abide by the legal requirements associated with these rights.

Take down policy

If you believe that this document breaches copyright please view our takedown policy at https://edshare.gcu.ac.uk/id/eprint/5179 for details of how to contact us. 


\section{Gender analysis of spending on the Scottish Modern Apprenticeship programme}

\section{Dr Jim Campbell}

Reader, School for Business and Society, Glasgow Caledonian University, Glasgow, UK

\section{Morag Gillespie}

Research Associate, Women in Scotland's Economy Research Centre, Glasgow Caledonian University, Glasgow, UK

\section{Corresponding Author:}

Jim Campbell

Address

Email: J.Campbell@gcu.ac.uk

Occupational gender segregation remains an enduring challenge everywhere and a key contributor to the gender pay gap. Gender Impact Analysis tools are an important aid for evaluating the impact of social and economic policies from a gender perspective. In particular, gender budget analysis can help to show the impact of public spending and the extent to which it can reinforce or break down persistent gender inequalities. 
A key component of the Scottish Government's employability strand of its Economic Strategy has been additional investment in the Modern Apprenticeship (MA) Programme.

As part of an ESRC-funded project, the authors undertook an assessment of the MA programme in Scotland using Gender Disaggregated Public Expenditure Incidence Analysis. This is a gender budget analysis tool that shows the gender responsiveness of budgets and specific policies by assessing the distribution of expenditure on men and women. Analysis of the investment in different occupational frameworks and at different levels of training found that, despite an increase in women's participation in MAs, significant occupation gender segregation persists. Men predominate in the higher level training programmes and women in the lower level apprenticeships, resulting in a substantial gender gap in public investment in the MA Programme.

This kind of approach to gender analysis has the potential to be an important tool for policy makers and practitioners to improve understanding of the implications of spending decisions and priorities and to contribute to developing strategies to tackle them in relation to gender, but also other protected characteristics such as disability, ethnic origin and age.

\section{Key Words}

Gender budgeting, public spending, occupational gender segregation, Scotland, training 


\section{Gender analysis of spending on the Scottish Modern Apprenticeship Programme}

\section{Introduction}

Resource allocation processes are built upon the assumption of rational, self-interested economic actors with little or no reference to gender. However the evidence suggests that men and women often have different policy experiences across a broad range of areas including healthcare, transport and criminal justice (Breitenbach and Wasoff, 2007). Similarly, gender is a key variable in determining individual and collective patterns of participation, for example with respect to economic activities such as paid and unpaid work, academic and vocational education and training or caring.

The way in which governments set policy objectives, priorities and budgets is often blind to gender differences (Elson, 1995), failing to recognise and account for the different situations and needs of women and men. As a result, resources can be allocated inefficiently and, in some instances, may actually serve to reinforce existing patterns of gender inequality, even when there is an explicit commitment to promote gender equality.

Gender Impact Analysis (GIA) is an important aid for evaluating the impact of social and economic policies from a gender perspective. In relation to public finance, gender responsive budgeting (GRB) initiatives have been developed over more than two decades as a means of advancing gender equality (Addabbo et al., 2015). GRB is "an analysis of the impact of the budget on gender equality and a process of changing budgetary decision-making and priorities." (Sharp and Broomhill, 2013:1). Initiatives have been developed at different levels of government, using a range of methods and 
approaches to reflect local conditions. GRB aims to help improve the quality of decision making in budget processes and build greater awareness, transparency and accountability (Elson \& Sharp, 2010). GRB advocates have argued that a gendered analysis of public expenditure offers an opportunity to evaluate the impact of social and economic policies from a gender perspective and to support actions to tackle or eliminate policy effects that may serve to replicate or exacerbate persistent gender inequalities.

There are a range of tools that can be used to evaluate the gender impact of public spending programmes, but perhaps one of the best known is gender-disaggregated public expenditure incidence analysis (GDPEIA) (Budlender et al., 1998). Expenditure incidence analysis (EIA) provides a way to measure the distribution of public expenditure and tax policies for different social groups, including identifying which groups gain and which lose. A gender disaggregated EIA shows the gender responsiveness of budgets and specific policies by assessing the impact of public expenditure on men and women. Austen et al. (2013) provide a comprehensive account of the development of GDPEIA and its usefulness in helping to deliver more gender aware policy outcomes. However they recognise that:

"Producing a gender disaggregated EIA is not enough to bring about gender responsive policy and budget changes." (Austen et al., 2013: 5)

As with any data analysis tools, GDPEIA has limitations: it can help to identify gender gaps, but needs to be used in combination with other forms of GIA and with understanding and awareness of the processes and actors involved in budgetary 
decision making (Austen et al., 2013). However it does provide a good starting point for understanding the gender impact of spending decisions.

This article explores the gender impact of public investment in the Modern Apprenticeship (MA) programme in Scotland using a GDPEIA. It is based upon research undertaken by the authors, as part of an ESRC funded knowledge exchange programme that involved the development of a toolkit for gender impact analysis of the MA programme. We begin with a brief explanation of the operation of the MA programme in Scotland followed by an analysis by gender of recent trends in terms of entry, participation and completion of MAs. The GDPEIA looked beyond headline figures to take account of the length and quality of training and indicates that public investment in this training programme benefits men more that women. The final section discusses the usefulness of this approach to analysis, particularly for the operation of the MA programme in the context of the Scottish Government's equality strategy.

\section{Modern Apprenticeships in Scotland}

MAs are a publicly funded training programme in Scotland which gives individuals the opportunity to combine employment and training by following an industry designed framework. It was introduced in 1994 to address a perceived lack of intermediate skills in the labour market and is aimed primarily at $16-19$ year olds, although it has been available to all ages since 2002 (those aged over 19 are known as Adult MAs). The MA programme is 'modern' in the sense that it has extended the concept of apprenticeship training into sectors of the economy not traditionally associated with 'on-the-job' training, 
such as retail, hospitality and childcare. MAs are offered at different levels from Level 2 (lowest) to Level 5 (highest). Successful completion of the MA results in the award of an accredited work based qualification, most often a Scottish Vocational Qualification (SVQ) at the respective level (Audit Scotland, 2014). The vast majority of MAs are either Level 2 which is the equivalent of the Intermediate Apprenticeship in England or Level 3 the equivalent of the Advanced Apprenticeship in England (Sosenko and Netto, 2013: 11).

All MAs have employed status meaning that, if not in employment already, potential candidates must find a suitable vacancy with an apprenticeship attached. Education and training are devolved matters and a range of agencies are involved in the design and delivery of MAs in Scotland. However the Scottish Government and Skills Development Scotland (SDS) have ultimate responsibility for the operation and public funding of MAs. SDS was formed in 2008 as a non-departmental public body bringing together careers, skills, training and funding services, with a budget in $2013 / 14$ of $£ 201.8 \mathrm{~m}$. Their main objective is to contribute to Scotland's "sustainable economic growth by supporting people and businesses to develop and apply their skills." (Skills Development Scotland, 2013: 2)

New starts and apprentices in training

Overall participation in the MA programme can be measured in three different ways.

- New starts (the number entering the programme for the first time);

- The total number in training at a particular point in time; or

- The number completing training. 
Historically there has been higher participation in MAs by men compared with women. However there has been a significant improvement in recent years in the number of women entering into apprenticeships. For example, in 2008/09 there was a total of 2,862 women who started an MA, representing $27 \%$ of the total new starts, but by $2012 / 13$ the number had increased to 11,040 , accounting for $43 \%$ of new starts (SDS, 2016).

Whilst this change is indicative of progress, a simple headcount of the number of women and men who enter the programme gives an incomplete picture of the gender impact of the public spending which is used to support the MA programme. The figures relating to the total number of apprentices in training at a given point reveal a different picture. Figure 1 shows that, although the number of women entering MAs has increased significantly over recent years, they still only represented about one third of the total in training in $2012 / 13$. It is also worth noting that, while the graph shows a slight narrowing of the gap between starts and in-training numbers amongst men between 2009 and 2013, there is not a significant change in the gap for women.

Figure 1. MA number of starts and in training by sex, 2009-13. 


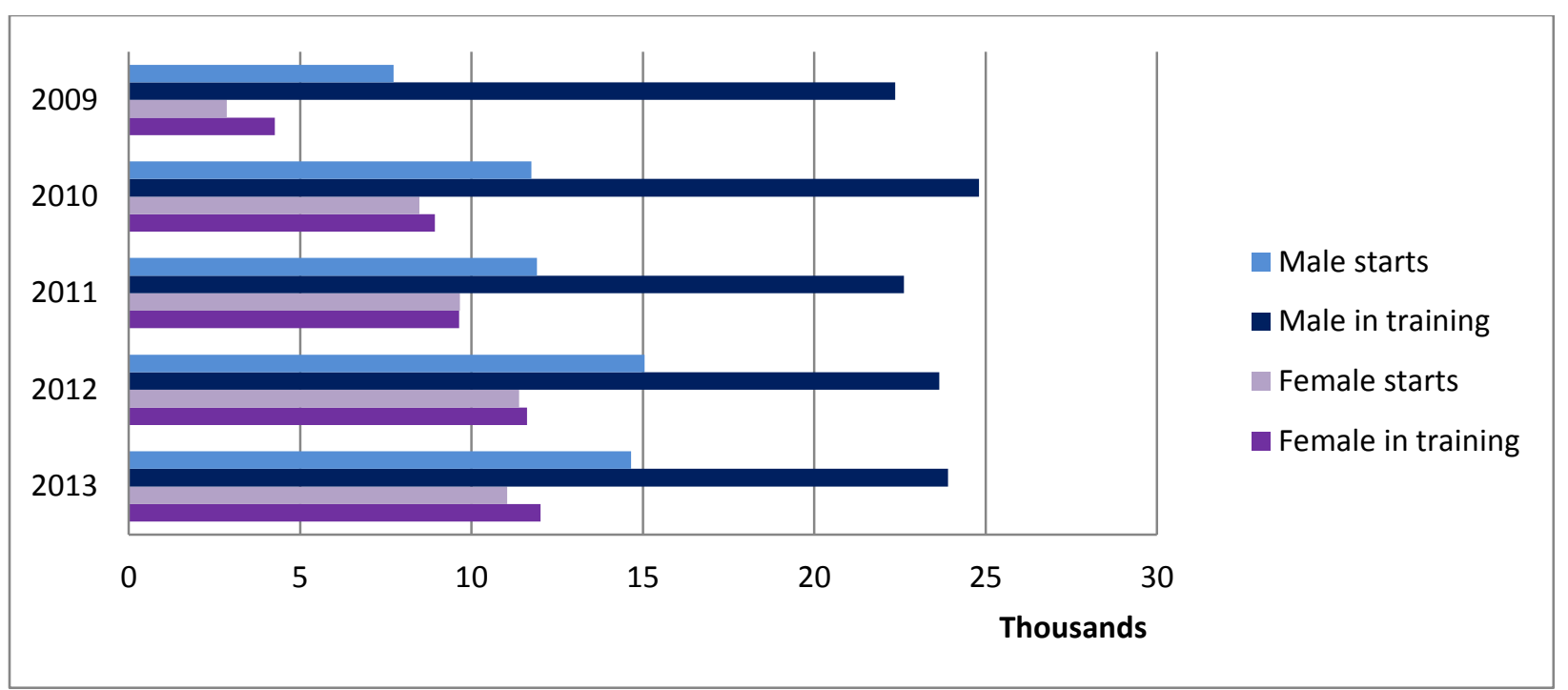

Source: Skills Development Scotland, 2016.

The discrepancy between the number of starts and those in training is in part explained by differences between individual frameworks in the length of training. For example, a Level 2 construction MA lasts, on average, two years compared to one year for a Level 2 hairdressing MA; a Level 3 MA in childcare lasts 12 months whilst, in contrast, a Level 3 apprenticeship in plumbing take four years to complete (Skills Development Scotland, 2012).

Although there are variations, the length of apprenticeships is broadly linked to the level of the apprenticeship which is also an indication of the quality of the training. Table 1 shows that marginally more women (51.1\%) than men started Level 2 apprenticeships in 2012-13 (5505 women compared with 5276 men) and marginally more were in training (5235 women compared with 5186 men). In response to demand for employers, the Level 2 MA was introduced in 2009 to replace the Skillseekers programme. Men are 
much more likely to start at Level 3 or higher and 3 times more likely to be in training at Level 3 or above.

Table 1. Starts in training by level of training and sex, 2012-13.

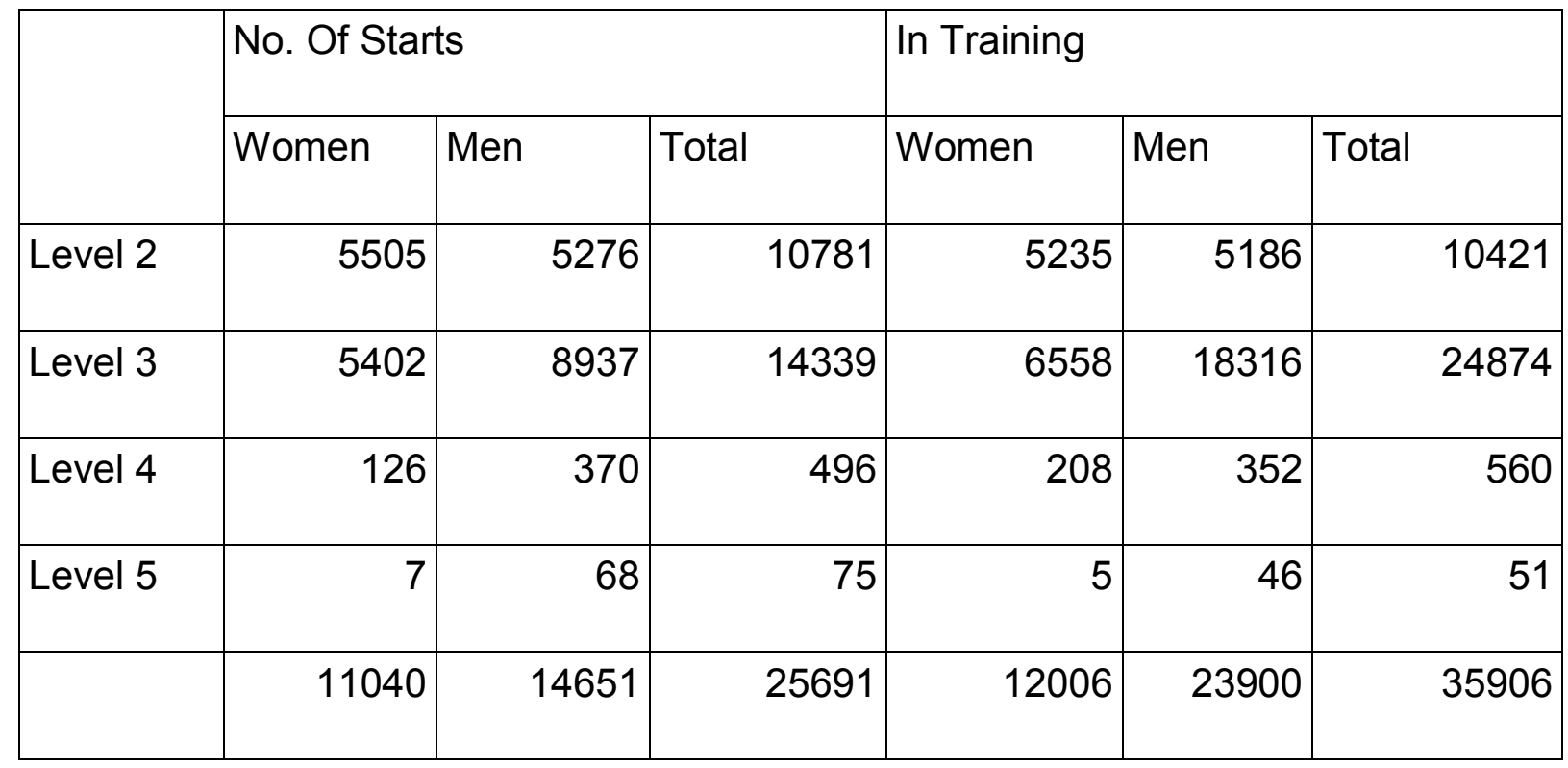

Source: Skills Development Scotland, 2016.

In terms of the age profile of MAs, almost half of new starts in 2012/13 were between 16-19. In this age group, there is little difference between the sexes in terms of new starts, but there is a bigger difference in the numbers in training. In March 2013 there were more than twice as many male apprentices in training aged 16-19 compared to women while the differences are less marked in the 20-24 age range (SDS, 2016).

The recent trend shows that, although women have an increased share of the total new starts, there is still a big gap in the numbers in training. This can be explained by men being more likely to have multi-year apprenticeships, while women tend to be in training 
for shorter periods. The main reason for this is the types of occupations and the level of MA which men and women enter into.

Previous research (Campbell et al,. 2005, 2006 \& 2009) has demonstrated how occupational gender segregation is an enduring feature of MAs and the labour market in general in Scotland and the UK. Table 2 provides a snapshot of the data for March 2013 of the 12 largest framework that account for three quarters of all apprenticeships. It shows that most frameworks reflect a high level of gender based occupational segregation. Four of the MA frameworks (construction, engineering, automotive and electrical) are almost exclusively male: these are all traditional craft apprenticeships. Three of the frameworks (health and social care, childcare and hairdressing) are female dominated and only three (hospitality, retail and management) are within $10 \%$ of gender balance.

The level of gender based occupational segregation in the largest frameworks has changed little over time: the traditional craft apprenticeships have become marginally less male dominated. For example, women accounted for $1.9 \%$ of engineer apprentices in 2008 , rising to $2.8 \%$ in 2013 ; but female domination in health and social care has become even more entrenched since women accounted for $80.3 \%$ of the total in 2008 , rising to $87.7 \%$ in 2013 (SDS, 2013).

Table 2. 12 largest MA frameworks, numbers in training in Scotland, March 2013, disaggregated by sex. 


\begin{tabular}{|c|c|c|c|c|}
\hline Frameworks & Total & Male & Female & \\
\hline & & No. & No. & $\%$ \\
\hline Construction combined $^{a}$ & 3857 & 3803 & 54 & $1.4 \%$ \\
\hline Engineering & 3671 & 3569 & 102 & $2.8 \%$ \\
\hline Hospitality & 3253 & 1562 & 1691 & $52.0 \%$ \\
\hline Automotive combined $^{a}$ & 2564 & 2525 & 39 & $1.5 \%$ \\
\hline Health \& Social Care & 2123 & 262 & 1861 & $87.7 \%$ \\
\hline Business \& Administration & 1989 & 523 & 1466 & $73.7 \%$ \\
\hline Electrical combined $^{a}$ & 1846 & 1823 & 23 & $1.2 \%$ \\
\hline Hairdressing combined $^{a}$ & 1818 & 123 & 1695 & $93.2 \%$ \\
\hline Freight Logistics combined $^{a}$ & 1663 & 1564 & 99 & $6.0 \%$ \\
\hline Childcare combined $^{a}$ & 1506 & 39 & 1467 & $97.4 \%$ \\
\hline Retail & 1413 & 571 & 842 & $59.6 \%$ \\
\hline Management & 1379 & 771 & 608 & $44.1 \%$ \\
\hline Total of above frameworks & 27082 & 17135 & 9947 & $36.7 \%$ \\
\hline
\end{tabular}

a. Where new frameworks are introduced, the transition period can include apprentices in both old and new frameworks - these are combined throughout this article forn each of the sectors identified here .

Source: Authors' analysis based on data from SDS (2016).

\section{MA completions}


The third way of analysing the trends in MAs is to look at completions. Overall, $77 \%$ of leavers in 2012-13 achieved an apprenticeship qualification, $76 \%$ of women and $77 \%$ of men. This means that almost a quarter of apprentices leave without achieving a qualification. However, this level of achievement represents an improvement compared with the period from 2008-11 when qualification levels were around $70 \%$ on average (SDS, 2016).

We have shown already that women form a slight majority of those in Level 2 apprenticeships. Comparison between the larger frameworks is also revealing when we look at achievements. Of the 12 largest frameworks, eight offered Level 2 MAs in 2013. Although women accounted for $51.1 \%$ of starts and $50.2 \%$ of those in training at Level 2, they accounted for $60 \%$ of all Level 2 achievers in 2012-13 (Table 3). Women's achievement rates were higher in most frameworks, but men's overall achievement rate was higher. This is explained in part by the fact that the two frameworks with the lowest achievement rates at Level 2, hairdressing and health and social care, are both female dominated.

At Level 3, women accounted for $38 \%$ of achievers overall, a proportion similar to female starts $(39.3 \%)$ and leavers $(37.2 \%)$ at this level (Table 3$)$, but higher than the proportion of females in training at Level $3(26.4 \%)$. The achievement rate amongst women at Level 3 is lowest in the male dominated frameworks of engineering and automotive industries, but overall a higher proportion of women achieved their apprenticeships at this level. 
Relatively few people achieve apprenticeships at Levels 4 and 5, in 2013, but male and female achievement rates were similar. At Level 4, 417 achieved apprenticeships (84\% of women and $87 \%$ of men) and 80 achieved a Level 5 ( $87 \%$ of women and $88 \%$ of men).

Table 3. Level 2 and Level 3 Achievement rates by sex, 2012-13.

\begin{tabular}{|c|c|c|c|c|c|c|}
\hline & \multicolumn{3}{|l|}{ Level 2} & \multicolumn{3}{|l|}{ Level 3} \\
\hline & \multirow[t]{2}{*}{$\begin{array}{l}\text { Female } \\
\% \text { of } \\
\text { achievers }\end{array}$} & \multicolumn{2}{|c|}{$\begin{array}{l}\text { Achievement } \\
\text { rates as \% of } \\
\text { leavers }\end{array}$} & \multirow[t]{2}{*}{\begin{tabular}{|l|} 
Female \\
$\%$ of \\
achievers
\end{tabular}} & \multicolumn{2}{|c|}{$\begin{array}{l}\text { Achievement } \\
\text { rates as \% of } \\
\text { leavers }\end{array}$} \\
\hline & & Female & Male & & Female & Male \\
\hline Automotive combined & 0 & - & 58 & 1 & 57 & 65 \\
\hline $\begin{array}{l}\text { Business \& } \\
\text { Administration }\end{array}$ & 72 & 81 & 77 & 80 & 85 & 74 \\
\hline Childcare combined & - & - & - & 98 & 74 & 57 \\
\hline $\begin{array}{l}\text { Construction } \\
\text { combined }\end{array}$ & 1 & 100 & 80 & 2 & 74 & 74 \\
\hline Electrical combined & - & - & - & 1 & 73 & 85 \\
\hline Engineering & - & - & - & 2 & 55 & 75 \\
\hline $\begin{array}{l}\text { Freight Logistics } \\
\text { combined }\end{array}$ & 11 & 85 & 89 & 3 & 75 & 86 \\
\hline Hairdressing & 92 & 67 & 60 & 93 & 79 & 79 \\
\hline
\end{tabular}




\begin{tabular}{|l|r|r|r|r|r|r|}
\hline combined & & & & & & \\
\hline Health \& Social Care & 86 & 63 & 61 & 86 & 71 & 58 \\
\hline Hospitality & 59 & 80 & 77 & 58 & 82 & 77 \\
\hline Management & - & - & - & 49 & 83 & 79 \\
\hline Retail & 61 & 77 & 73 & 64 & 67 & 61 \\
\hline Total & 60 & 73 & 77 & 38 & 78 & 76 \\
\hline
\end{tabular}

Source: Skills Development Scotland, 2016.

\section{The gender impact of public spending on MAs}

As the number of both men and women entering MAs has increased, so too has the level of public support. Annual public spending on the MA programme increased from around $£ 60 \mathrm{~m}$ in $2008 / 9$ to $£ 75 \mathrm{~m}$ in $2012 / 13$ representing a $24 \%$ increase in real terms (Audit Scotland 2014: 7). About 25\% of MA spending in 2012/13 was for new starts in the first year of training, the rest was for continuing apprentices who started training in previous years. The increase in spending reflects the Scottish Governments target to provide 25,000 new MA places each year between 2011/12 and 2015/16 (Audit Scotland, 2014: 5). However the actual spending in real terms per apprentice has gone down by $7.3 \%$ : in 2008/09 spending per apprentice in training was around $£ 2,300$ compared to $£ 2,100$ in 2012/13 (Audit Scotland, 2014: 18).

GDPEIA Analysis 
In order to assess the gender inclusiveness of public spending on MAs in Scotland, a GDPEIA was undertaken. Basically, a GDPEIA involves identifying a unit cost of a service or programme to identify the value of expenditure on the women and men involved, this can be expressed as male and female shares (Elson, 2002). As already identified, funding for apprenticeships varies considerably between Frameworks and according to age group and the level of training, so we aimed to conduct a more detailed analysis beyond identifying a single beneficiary or unit cost.

The analysis was based on unpublished data provided by SDS for 2012-13 and was applied only to the 12 largest frameworks already discussed. The funding attributable is assessed according to achievements rather than start, in-training or leaver numbers because this group of apprentices attracts full funding, including the final tranche that is payable only on successful completion. Due to the relatively small numbers undertaking Level 4 and 5 apprenticeships these have been excluded from the analysis.

Age is a significant factor for the level of funding for apprenticeships, a simple count of women and men was insufficient. The gender-disaggregated funding was estimated to take account of the fact that apprentice numbers for any given framework are not evenly spread between the age groups and the data were weighted to reflect the proportions in each of the three age groups.

The example of hospitality shows how the weighting was done. Funding for apprentices in that framework varies for each age group and for Level 2 or Level 3 apprenticeships. At Level 2 the funding across age groups is $£ 3,050$ for $16-19$; $£ 1,550$ for $20-24$; and $£ 500$ for $25+$. In 2012/13 a total of 2,521 people successfully completed Level 2 
hospitality apprenticeships: they included 991 16-19 years olds, 752 20-24 years old and 778 aged $25+$. An average funding rate for the 2,521 people who achieved their hospitality apprenticeship in 2012-13 was apportioned on the following basis:

- For age 16-19: $991 / 2521$ at $£ 3050=£ 1199$

- For age $20-24: 752 / 2521$ at $£ 1550=£ 462$

- For age $25+: 778 / 2521$ at $£ 500=£ 154$

This results in overall average funding per Level 2 apprenticeship of $£ 1,816$, whereas a crude average of the three funding rates, assuming the same proportions in each age group, would be $£ 1,700$. In the absence of more precise data, this approach is considered more sensitive to both the level of funding and age of trainees which can vary considerably between frameworks. These calculations were applied to each framework and level of apprenticeship to provide the estimates summarised below.

\section{GDPEIA analysis of 12 largest MA frameworks}

Within the 12 largest frameworks, there were eight frameworks that offered Level 2 apprenticeships. In these eight frameworks, there is considerable variation in the average funding rate, even at Level 2 (Table 4). However, funding reflects broadly the balance of achievers at this level (60\% female). In 2012-13, overall, approximately $£ 11 \mathrm{~m}$ of public funding was attached to these Level 2 apprenticeships, of which $62 \%$ went to female apprentices and $38 \%$ to male apprentices.

Table 4. Level 2 Achievers in the 12 largest MA frameworks, 2012-13: estimated funding, disaggregated by sex. 


\begin{tabular}{|c|c|c|c|c|c|c|c|}
\hline & Achiever & & & Estimated & funding $£$ & & \\
\hline & Female & Male & rate $£$ & Female & Male & All & $\begin{array}{l}\text { Female } \\
\%\end{array}$ \\
\hline $\begin{array}{l}\text { Automotive } \\
\text { combined }\end{array}$ & 0 & 25 & 2,837 & 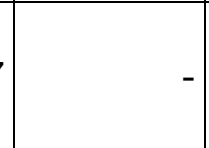 & 70,920 & 70,920 & $0 \%$ \\
\hline $\begin{array}{l}\text { Business \& } \\
\text { Administration }\end{array}$ & 496 & 192 & 2,440 & $1,210,011$ & 468,391 & $1,678,403$ & $72 \%$ \\
\hline $\begin{array}{l}\text { Construction } \\
\text { combined }\end{array}$ & 2 & 388 & 2,451 & 4,903 & 951,144 & 956,046 & $1 \%$ \\
\hline $\begin{array}{l}\text { Freight Logistics } \\
\text { combined }\end{array}$ & 57 & 458 & 720 & 41,045 & 329,801 & 370,847 & $11 \%$ \\
\hline $\begin{array}{l}\text { Hairdressing } \\
\text { combined }\end{array}$ & 555 & 49 & 2,526 & $1,402,021$ & 123,782 & $1,525,803$ & $92 \%$ \\
\hline $\begin{array}{l}\text { Health \& Social } \\
\text { Care }\end{array}$ & 736 & 117 & 1,569 & $1,154,716$ & 183,562 & $1,338,278$ & $86 \%$ \\
\hline Hospitality & 848 & 579 & 1,816 & $1,539,636$ & $1,051,238$ & \begin{tabular}{|l|l|}
$2,590,874$ \\
\end{tabular} & $59 \%$ \\
\hline Retail & 722 & 454 & 2,058 & $1,485,932$ & 934,367 & $2,420,299$ & $61 \%$ \\
\hline Totals & 3416 & 2262 & & $6,838,264$ & $4,113,205$ & \begin{tabular}{|l|l}
$10,951,469$ \\
\end{tabular} & $62 \%$ \\
\hline
\end{tabular}

Source: authors' calculations based on unpublished data provided by SDS

Table 5 provides estimates of funding for Level 3 achievers in the 12 largest frameworks in 2012-13. The figures shows that, although women accounted for $38 \%$ of achievers, they had only $34 \%$ of funding attached to their apprenticeships compared with $66 \%$ attached to male apprentices. This reflects the higher numbers of male achievers in 
frameworks with large numbers of apprenticeships at higher funding rates, including engineering and construction.

Table 5. Level 3 achievers in the 12 largest frameworks, 2012-13: estimated funding disaggregated by sex.

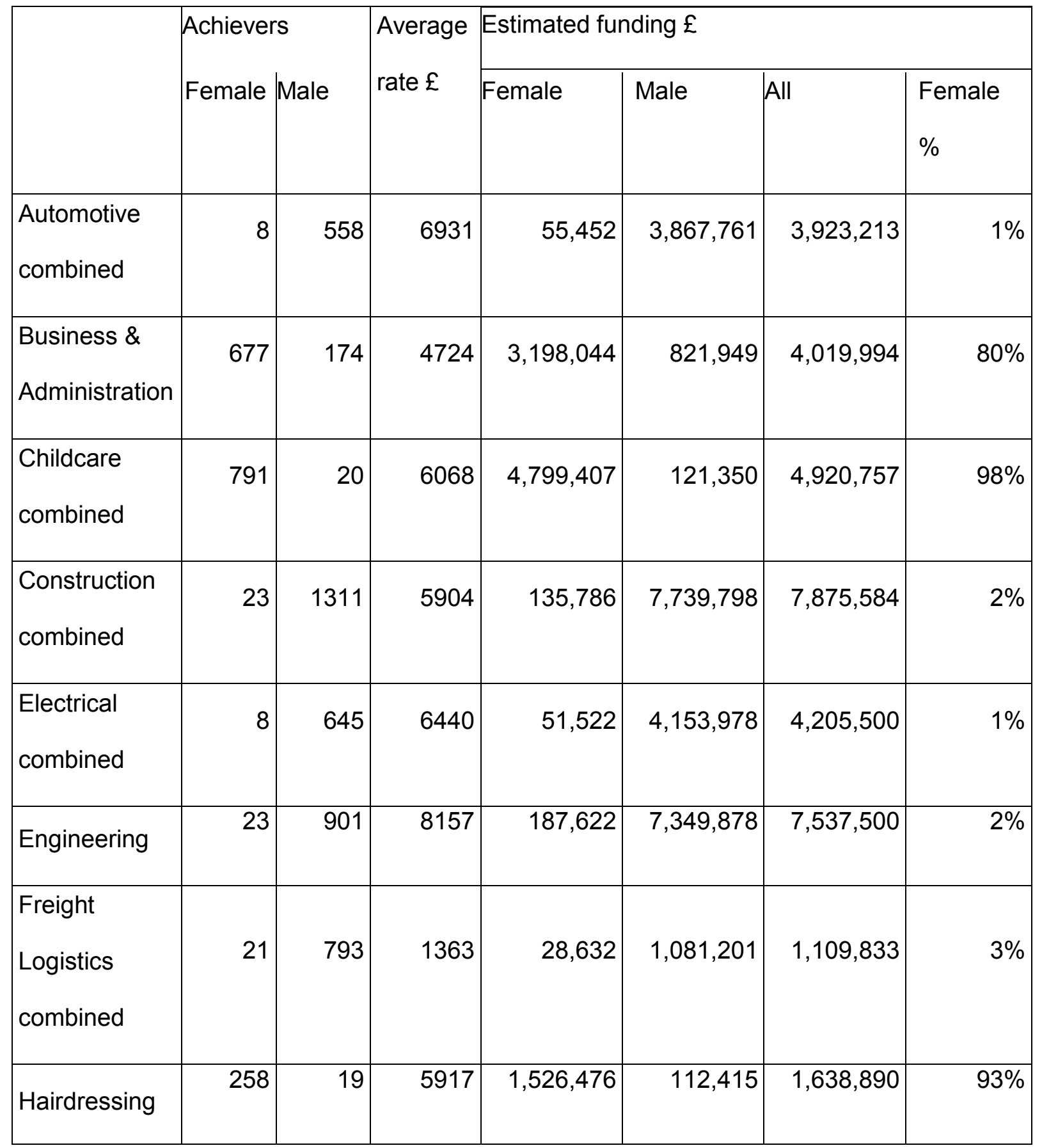




\begin{tabular}{|l|r|r|r|r|r|r|r|}
\hline Combined & & & & & & & \\
\hline Social Care & 313 & 51 & 3249 & $1,016,881$ & 165,690 & $1,182,571$ & $86 \%$ \\
\hline Hospitality & 636 & 458 & 3759 & $2,390,487$ & $1,721,451$ & $4,111,939$ & $58 \%$ \\
\hline Management & 392 & 409 & 1657 & 649,579 & 677,750 & $1,327,329$ & $49 \%$ \\
\hline Retail & 143 & 80 & 4048 & 578,848 & 323,831 & 902,680 & $64 \%$ \\
\hline Totals & 3293 & 5419 & & $14,618,736$ & $28,137,054$ & $42,755,790$ & $34 \%$ \\
\hline
\end{tabular}

Source: authors calculations based on unpublished data provided by SDS.

Our analysis indicates that there were 14,390 achievers across the 12 largest frameworks in 2012-13 at Levels 2 and 3 who had estimated funding of around $£ 53.7 \mathrm{~m}$ attached to their apprenticeships (Table 6). While the achievements of and funding for women's apprenticeships are closely matched to men's at Level 2, the disparity between them increases significantly at Level 3 . This disparity works in favour of male apprenticeships so that, although female apprentices accounted for $46.6 \%$ of achievers at Levels $2 \& 3$, they attracted only $40 \%$ of the total funding, approximately $£ 21.5 \mathrm{~m}$ compared to a public spend of $£ 32.2 \mathrm{~m}$ on male apprenticeships.

Table 6: Achievers in the 12 largest frameworks, 2012-13, estimated funding totals disaggregated by sex.

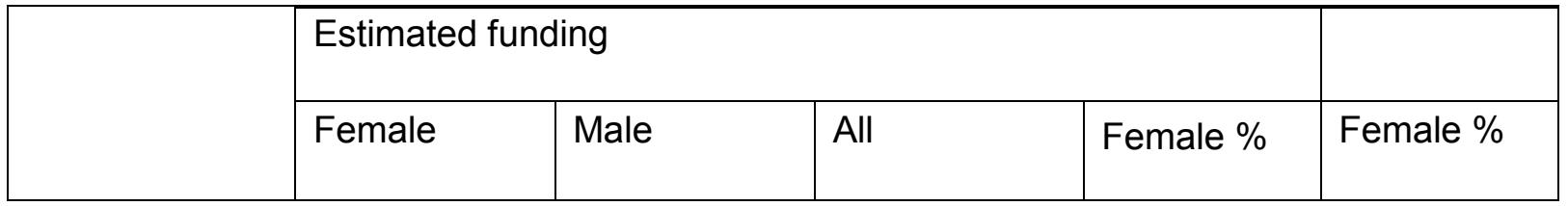




\begin{tabular}{|l|r|r|r|r|r|} 
& & & & funding & achievers \\
\hline All level 2 & $£ 6,838,264$ & $£ 4,113,205$ & $£ 10,951,469$ & $62.4 \%$ & $60.2 \%$ \\
\hline All level 3 & $£ 14,618,736$ & $£ 28,137,054$ & $£ 42,755,790$ & $34.2 \%$ & $37.8 \%$ \\
\hline Total & $£ 21,457,000$ & $£ 32,250,259$ & $£ 53,707,259$ & $40.0 \%$ & $46.6 \%$ \\
\hline
\end{tabular}

\section{Informing progress towards gender equality?}

The Scottish Government's Skills Strategy (2010) identified that progress was being made towards the desired goal of gender balance in MAs. The recent trends in MAs indicate that overall female participation has improved, particularly in relation to new starts. Women's share of new starts increased from $27 \%$ in $2008 / 9$ to $43 \%$ in 2012/13. This is also reflected in an increase in the number of women in training which rose from $16 \%$ in 2009 to $33.4 \%$ in 2013 . However there is still a significant gap between the percentage share of new starts and women's share of those in training. This gap can be explained by two factors: firstly, disparities in the length of apprenticeship training can vary between six months and four years; secondly, the types of apprenticeships which women tend to undertake are, on the whole, of shorter duration than those undertaken by men.

In the 12 largest frameworks there is still a significant level of occupational segregation with women concentrated in childcare, hairdressing and health \& social care. These three frameworks accounted for $42 \%$ of all women in training in 2013. In contrast the construction, engineering and automotive frameworks accounted for $41 \%$ of all men in training in 2013. Male dominated frameworks tend to last longer than female dominated 
frameworks. Women are concentrated in apprenticeships with lower qualification levels and shorter training that generally attract less funding.

The GDPEIA helps to expose the way in which headline figures can conceal gendered impacts. In the example of the MA programme, funding arrangements are complex and are compounded by occupational gender segregation of men and women into particular frameworks and sectors, combined with women's concentration in Level 2 apprenticeships. The result is a lower level of public spending on women compared to men in the MA programme. Apprenticeships at Level 3 and above accounted for $76 \%$ of total MA spending in 2012/13.

The effectiveness of SDS administration of the MA programme was the subject of an audit by Audit Scotland. In relation to gender equality, their report also acknowledges gender disparities in terms of the beneficiaries of public spending on the programme. They highlighted that women accounted for $43 \%$ of new starts in $2012 / 13$ but benefited from only one third of the public funding (Audit Scotland 2014: 25). Men aged 16-19 are the largest group of apprentices, usually attached to apprenticeships with higher contribution rates: Audit Scotland cited the example of engineering in which $75 \%$ of people starting an apprenticeship, which attracts a public spending contribution rate of $£ 9,000$, were 16-19 year old men (Audit Scotland, 2014: 24).

Evidence from a programme of research over a decade on gender inequality and occupational segregation has helped to put occupational segregation more firmly on the policy agenda (Thomson, 2016), but progress has been very slow. Skills Development Scotland (SDS) has been very successful in recent years in meeting some of the targets 
set by the Scottish Government, in particular increasing the number of young people entering apprenticeship training and who successfully complete that training. However they have had less success at addressing the gender imbalance which exists in many frameworks. Indeed, despite a commitment by both SDS and the Scottish government to tackle gender based occupational segregation (Scottish Government, 2014) the operation of the MA, particularly in terms of spending, continues to favour young men and disadvantage women.

In recommending what should be done to develop Scotland's young workforce, the Wood Commission included amongst its recommendations that SDS should develop an action plan, with 'realistic but stretching improvement targets' on gender inequalities in the MA programme (Scottish Government, 2014b: 38). The Scottish government recently set SDS a target to reduce to $60 \%$ the percentage of MA frameworks where the gender balance is $75: 25$ or worse by 2021 from its level in $2014 / 15$ of $72 \%$ (Scottish Government, 2015: 39). Given the entrenched nature of occupational segregation, this can be viewed as an ambitious target and, if achieved, would go some way to reducing the disparities in public spending between women and men apprentices. In its Equality Action Plan published in 2015, SDS outlined a series of measures which they believe will help them to achieve the objective of significantly reducing gender segregation in the MA programme. (SDS, 2015). The measures include: early intervention in schools to challenge gender stereotypes; work with the Construction Industry Training Board (CiTB) to encourage more women into the industry; and greater support for young people entering apprenticeships where their sex is in the minority. 
However, whilst the sincerity is not in doubt of either the Scottish government or SDS in terms of their desire to tackle and reduce gender based occupational segregation, and although target setting is a useful way to focus efforts, the targets themselves need to be clear and fit for purpose. Our research shows that headline 'new start' figures conceal the extent of gender disparities. It is not clear whether the target to reduce the number of frameworks where the gender balance is $75: 25$ or worse refers to new starts, numbers in training or completions. In addition, it could create an incentive for SDS to concentrate on those frameworks which are closer to 75:25 gender balance or, indeed, frameworks with few apprentices where small changes could make a bigger difference, in order to meet the target set by the Scottish government. The SDS Equality Strategy acknowledges that:

"the main cause of gender segregation is traditional, cultural norms and out-of-date value systems, including stereotypical views among key influencers (e.g. parents, teachers, peers) regarding young people's choices in school subjects and jobs." (SDS, 2015:11)

However, even at the point of publishing the action plan, SDS also acknowledges attaining the target "may not necessarily reflect the cultural shift required to address gender bias" and will develop "a range of indicators that demonstrate progress in addressing the strong gender bias in some MA frameworks." (SDS, 2015:39) This reinforces concerns that the target may not be effective at addressing the underlying causes of gender segregation, even if it is achieved, casting doubt on the value of the target from the outset. 


\section{Conclusions}

As we have demonstrated, the extent of gender segregation in the MA programme does vary depending upon how participation is measured. The analysis in this article has highlighted the persistence of occupational segregation and the GDPEIA has shown how this results in significant gender disparities in public spending on apprenticeships.

Given the many and varied causes of segregation and in order to make significant progress on these issues in a more reasonable period of time, our research leads us to suggest that a National Strategy to address occupational gender segregation is required,. A National Strategy that includes planned and co-ordinated action by stakeholders in the education sector, as well as relevant policy actors and public and private sector employers would ensure that the issue is recognised as the responsibility of all involved. In addition, financial incentives for employers to take on atypical apprenticeships might be necessary in the short run to challenge entrenched gender stereotyping.

The promotion of gender equality has been a key policy goal of Scottish governments since the establishment of the devolved administrations in 1999. The approach adopted involved a wider focus on equality, including gender and other protected characteristics. A Public Sector Equality Duty (PSED) was introduced in April 2011, requiring:

"that public authorities give proper consideration to equality in their day to day work in shaping policy, delivering services and in their employment practices." (Equality and Human Rights Commission, 2015: 1) 
The Scottish Government is also progressing integration of equality analysis into the Budget process and, since 2009, produces an Equality Budget Statement attached to the annual national Draft Budget in an effort "to expose the value of resources allocated for the advancement of equality and the process by which such decisions are made". (O'Hagan and Gillespie, 2016: 51) Although O'Hagan and Gillespie (2016) argue that a systematic equality analysis of the Scottish Budget remains some way off the Scottish Government's refreshed Economic Strategy (2015) presents tackling inequality and improving competitiveness as "mutually reinforcing objectives" (Scottish Government, 2015: 77). The strategy recognises the need to tackle skills and attainment gaps and gender based occupational segregation as key issues in the Scottish labour market.

The objective of the PSED is to eliminate policy effects that may serve to replicate persistent gender inequalities. The GDPEIA helped to reveal who gains and who loses from public spending decisions on MAs and demonstrates that the way in which the MA programme operates and the way training is funded does perpetuate gender inequality. Although the limits of gender disaggregated data analysis tools for bringing about change (Austen et al., 2015) do need be recognised, such tools can play an important role in making the impact of spending decisions more transparent and act in support of approaches that move beyond headline figures towards implementing more transformative change. In Scotland, where there is a commitment to improving the transparency of budgetary decision making in relation to equality, such tools will be equally important for understanding the extent of progress being made in areas such as MA training in what will need to be a long term approach. The potential should also be 
explored for this kind of analysis to inform equal treatment strategies in relation to other protected characteristics such as disability, ethnic origin and age.

\section{Funding Acknowledgement}

This work was supported by the Economic and Social Research Council (ES/Koo568/1).

\section{References}

Addabbo T, Gunluk-Senesen G and O'Hagan A (2015) Gender Budgeting: Insights from current methodologies and experiences in Europe Politica Economica/ Journal of Economic Policy XXXI(2): 125-134.

Audit Scotland (2014) Modern Apprenticeships. Edinburgh: Scottish Government, March 2014. Available

at: http://www.auditscotland.gov.uk/docs/central/2014/nr 140313 modern apprenticeships .pdf (accessed 17 January 2016).

Austen S Costa M Sharp R and Elson D (2013) Expenditure Incidence Analysis: A Gender-Responsive Budgeting tool for educational expenditure in Timor-Leste? Feminist Economics 19(4): 1-24.

Breitenbach E and Wasoff $\mathrm{F}$ (2007) A gender audit of statistics: comparing the position of women and men in Scotland. Edinburgh: Scottish Executive. Available at: http://www.scotland.gov.uk/Resource/Doc/172901/0048232.pdf (accessed 18 January 2016). 
Budlender D Sharp R and Allen K (1998) How to do a gender-sensitive budget analysis:

Contemporary research and practice. Commonwealth Secretariat: London

Campbell J McKay A and Thomson E (2005) How modern is the modern apprenticeship? Local Economy 20(3): 294-304.

Campbell J McKay A and Thomson E (2006) From Gender Blind to Gender Focused: Re-evaluating the Scottish Modern Apprenticeship Programme. Scottish Affairs 57(1): 70-89.

Campbell J Gillespie M McKay A and Meikle A (2009) Jobs for the Boys and the Girls: Promoting a Smart Successful Scotland three years on. Scottish Affairs 66 (1): 65-83.

Elson D (1995) Male Bias in the Development Process. Manchester: Manchester University Press.

Elson D (2002) Gender Responsive Budget Initiatives: Key Dimensions and Practical Examples. In: UNIFEM, Gender Budget Initiatives, New York: UNIFEM, pp.15-29.

Elson D and Sharp R (2010) Gender-responsive budgeting and women's poverty. In: Chant S (ed) International Handbook of Gender and Poverty: Concepts, Research, Policy. Cheltenham: Edward Elgar Publishing, pp. 522-527.

Equality and Human Rights Commission (2015) Measuring Up? Report 4: Performance. Report of public authorities performance in meeting the Scottish Specific Equality Duties. Scotland: Equality and Human Rights Commission, September 2015. Available at: 
http://www.equalityhumanrights.com/sites/default/files/publication pdf/measuring up 4 performance final 1.pdf (accessed 21 January 2016)

O'Hagan A and Gillespie M (2016) Gender budgeting in Scotland: seeking transformative change through public spending. In Campbell $\mathrm{J}$ and Gillespie $\mathrm{M}$ (eds) Feminist Economics and Public Policy: Reflections on the Work and Impact of Ailsa McKay. Abingdon: Routledge, pp. 50-58.

Scottish Government (2010) Skills for Scotland: Accelerating the Recovery and Increasing Sustainable Economic Growth. Edinburgh: Scottish Government. Available at http://www.scotland.gov.uk/Resource/Doc/326739/0105315.pdf (accessed 11 April 2016).

Scottish Government (2014) Developing the Young Workforce, Scotland's Youth Employment Strategy, Implementing the Recommendations of the Commission for Developing Scotland's Young Workforce. Edinburgh: Scottish Government.

Scottish Government (2014b) Education Working for All! Commission for Developing Scotland's Young Workforce Final Report. Edinburgh: Scottish Government. Available from: www.gov.scot/

Publications/2014/06/4089 (accessed 6 August 2015).

Scottish Government (2015) Scotland's Economic Strategy. Edinburgh: Scottish Government. March: Available at http://www.gov.scot/Resource/0047/00472389.pdf 
(accessed 22 January 2016).

Sharp R and Broomhill R (2013) A case study of Gender Responsive Budgeting in Australia. London: Commonwealth Secretariat.

Skills Development Scotland (2012) Evidence to Education and Culture Committee of the Scottish Parliament December 2012. Available at:

http://www.scottish.parliament.uk/S4 EducationandCultureCommittee/General\%20Doc uments/Danny Logue Letter.pdf (Accessed 20th January 2016).

Skills Development Scotland (2013) Operating Plan 2013/14. Glasgow: Skills Development Scotland. Available at: www.skillsdevelopmentscotland.co.uk/media/815091/sds operating plan 2013-14.pdf (accessed 17 January 2016).

Skills Development Scotland (2015) Equalities Action Plan for Modern Apprenticeships in Scotland. Glasgow: Skills Development Scotland: December Available at https://www.skillsdevelopmentscotland.co.uk/media/40691/2869_sds_equalities_action_ plan_digital_v7.pdf (Accessed 17 January 2016).

Skills Development Scotland (2016) Publications and Statistics web page. Available at https://www.skillsdevelopmentscotland.co.uk/publications-statistics/\# (accessed 10 January 2016).

Sosenko F and Netto G (2013) Scotland-focused analysis of statistical data on participation in apprenticeships in four UK countries. Edinburgh: Heriot Watt University. Available at 
art 1 final report 170713.pdf (accessed February 2016).

Thomson E (2016) Occupational segregation and Modern Apprenticeships in Scotland. In Campbell J and Gillespie M (eds) Feminist Economics and Public Policy: Reflections on the work and impact of Ailsa McKay. London: Routledge, pp. 130-142. 